Article

\title{
Complex Investigation of High Efficiency and Reliable Heterojunction Solar Cell Based on an Improved $\mathrm{Cu}_{2} \mathrm{O}$ Absorber Layer
}

\author{
Laurentiu Fara $^{1,2, *(\mathbb{D} \text {, Irinela Chilibon }}{ }^{3}$, Ørnulf Nordseth ${ }^{4}$, Dan Craciunescu ${ }^{1}$, Dan Savastru ${ }^{3}$, \\ Cristina Vasiliu ${ }^{3}$, Laurentiu Baschir ${ }^{3}{ }^{(1)}$, Silvian Fara ${ }^{1}$, Raj Kumar $\left.{ }^{5}{ }^{(}\right)$, Edouard Monakhov ${ }^{5}$ and \\ James P. Connolly 6 (D) \\ 1 Department of Physics, Faculty of Applied Sciences, Polytechnic University of Bucharest, 060042 Bucharest, \\ Romania; dan.craciunescu@sdettib.pub.ro (D.C.); silvian.fara@gmail.com (S.F.) \\ 2 Academy of Romanian Scientists, 050091 Bucharest, Romania \\ 3 National Institute of Research and Development for Optoelectronics (INOE-2000), 077125 Bucharest, \\ Romania; chilib@inoe.ro (I.C.); dsavas@inoe.ro (D.S.); icvasiliu@inoe.ro (C.V.); \\ baschirlaurentiu@inoe.ro (L.B.) \\ 4 Institute for Energy Technology (IFE), P.O. Box 40, NO-2027 Kjeller, Norway; Ornulf.Nordseth@ife.no \\ 5 Department of Physics/Center for Materials Science and Nanotechnology (SMN), University of Oslo, \\ P.O. Box 1048 Blindern, N-0316 Oslo, Norway; raj.kumar@smn.uio.no (R.K.); \\ eduard.monakhov@fys.uio.no (E.M.) \\ 6 GeePs (Group of electrical engineering-Paris), UMR CNRS 8507, CentraleSupélec, Univ. Paris-Sud, \\ Université Paris-Saclay, Sorbonne Université, 11 rue Joliot-Curie, 91192 Plateau de Moulon, \\ Gif-sur-Yvette CEDEX, France; jpgconnolly@gmail.com \\ * Correspondence: lfara@renerg.pub.ro
}

Received: 30 July 2020; Accepted: 31 August 2020; Published: 8 September 2020

check for updates

\begin{abstract}
This study is aimed at increasing the performance and reliability of silicon-based heterojunction solar cells with advanced methods. This is achieved by a numerical electro-optical modeling and reliability analysis for such solar cells correlated with experimental analysis of the $\mathrm{Cu}_{2} \mathrm{O}$ absorber layer. It yields the optimization of a silicon tandem heterojunction solar cell based on a $\mathrm{ZnO} / \mathrm{Cu}_{2} \mathrm{O}$ subcell and a c-Si bottom subcell using electro-optical numerical modeling. The buffer layer affinity and mobility together with a low conduction band offset for the heterojunction are discussed, as well as spectral properties of the device model. Experimental research of $\mathrm{N}$-doped $\mathrm{Cu}_{2} \mathrm{O}$ thin films was dedicated to two main activities: (1) fabrication of specific samples by DC magnetron sputtering and (2) detailed characterization of the analyzed samples. This last investigation was based on advanced techniques: morphological (scanning electron microscopy-SEM and atomic force microscopy-AFM), structural (X-ray diffraction-XRD), and optical (spectroscopic ellipsometry-SE and Fourier-transform infrared spectroscopy-FTIR). This approach qualified the heterojunction solar cell based on cuprous oxide with nitrogen as an attractive candidate for high-performance solar devices. A reliability analysis based on Weibull statistical distribution establishes the degradation degree and failure rate of the studied solar cells under stress and under standard conditions.
\end{abstract}

Keywords: silicon tandem heterojunction solar cell; $\mathrm{N}$-doped $\mathrm{Cu}_{2} \mathrm{O}$ absorber layer; $\mathrm{Al}: \mathrm{ZnO}(\mathrm{AZO})$; numerical electro-optical modeling; scanning electron microscopy (SEM); atomic force microscopy (AFM); X-ray diffraction (XRD); spectroscopic ellipsometry (SE); Fourier-transform infrared (FTIR) spectroscopy; degradation degree; failure rate 


\section{Introduction}

Cuprous oxide has attracted much attention for thin film photovoltaic applications due to its high absorption coefficient in the visible region [1]. It is also a nontoxic, low cost material, which is abundant in the Earth's crust. $\mathrm{Cu}_{2} \mathrm{O}$ crystallizes in a cubic structure with a lattice constant of $4.269 \AA$, where the copper $(\mathrm{Cu})$ and oxygen $(\mathrm{O})$ atoms are arranged in face-centered cubic $\left(\mathrm{fcc}_{\mathrm{c}}\right)$ and body-centered cubic (bcc) sub-lattices, respectively. $\mathrm{Cu}_{2} \mathrm{O}$ is a natural p-type semiconductor with a direct band gap of about $2.1 \mathrm{eV}$, with negatively charged $\mathrm{Cu}$ vacancies and $\mathrm{O}$ interstitials [2].

Concerning fabrication, cuprous oxide thin films have been prepared by a wide range of synthesis techniques including reactive sputtering, sol-gel technique, plasma evaporation, thermal oxidation, chemical vapor deposition, anodic oxidation, reactive sputtering, electrodeposition, and so on [3]. Wang et al. have demonstrated that the incorporation of nitrogen in thin films can significantly decrease the resistivity [4]. Nitrogen doping in $\mathrm{Cu}_{2} \mathrm{O}$ has been shown to provide an effective approach to reducing the resistivity/enhancing the hole concentration, as the reported carrier concentrations in $\mathrm{N}$-doped $\mathrm{Cu}_{2} \mathrm{O}$ thin films are of the order of $10^{16}-10^{18} \mathrm{~cm}^{-3}$.

Sberna et al. [5] analyzed the effects of nitrogen doping, introduced by ion implantation, on the parameters of $\mathrm{Cu}_{2} \mathrm{O}$ films. They show that the optimization of structural, optical, and electrical properties of $\mathrm{Cu}_{2} \mathrm{O}$ thin films synthesized by non-reactive magnetron sputtering can be achieved by post-deposition thermal annealing in oxygen atmosphere.

Foremost among the challenges in metal oxide solar cells development are the improvement of the performance and reliability of these devices. A potential candidate for high-efficiency metal oxide solar cells, such as the $\mathrm{Cu}_{2} \mathrm{O} / \mathrm{ZnO} / \mathrm{c}-\mathrm{Si}$ tandem heterojunction solar cell, could theoretically reach a conversion efficiency above 30\% [6]. The key to achieving higher efficiencies for solar cells made from these materials is to tune the optical and electrical properties of absorber material in the solar cell, such as cuprous oxide $\left(\mathrm{Cu}_{2} \mathrm{O}\right)$.

The conversion efficiency for the current $\mathrm{ZnO} / \mathrm{Cu}_{2} \mathrm{O}$ heterojunction solar cells is around $8 \%$, while the potential is $14 \%$ conversion efficiency. Factors like low power conversion efficiency, high defect density, and large conduction band offset for the metal oxide heterojunction imply that there is room for research to further optimize the device. Probe-scanning instruments can provide valuable information towards the characterization and optimization of solar cell layers. However, interface defect states pose a challenge in reaching efficiencies close to the theoretical maximum. Currently, the conversion efficiency for cuprous oxide heterojunctions has the potential to reach $14 \%$ as reported by Takiguchi et al. [7] and a theoretical maximum efficiency of around 19\%.

The present study is based on numerical electro-optical modeling and reliability analysis and is dedicated to increasing the performance and reliability of heterojunction solar cells [8-10]; it is correlated with the experimental investigation (morphological, structural, and optical) of an improved $\mathrm{Cu}_{2} \mathrm{O}$ absorber layer. Its morphological and structural characterization is based on SEM, AFM, and XRD analyses [11]. The optical characterization of the $\mathrm{Cu}_{2} \mathrm{O}$ layer uses FTIR spectroscopy and SE analyses [12]. Furthermore, a statistical reliability study is carried out, analyzing the lifetime, degradation degree, and failure rate of the studied solar cells.

\section{Numerical Modeling of $\mathrm{Cu}_{2} \mathrm{O}$ Heterojunction Solar Cell}

\subsection{Diagram of the Solar Cell Simulation Model}

A schematic representation of the $\mathrm{Cu}_{2} \mathrm{O}$ heterojunction solar cell simulation model is shown in Figure 1. The device structure includes a quartz glass superstrate, an aluminum-doped $\mathrm{ZnO}(\mathrm{AZO}) \mathrm{n}+$ emitter layer, a $\mathrm{Cu}_{2} \mathrm{O}$ p-type absorber layer, and a bottom $\mathrm{Cu}_{2} \mathrm{O}: \mathrm{N}$ layer. 


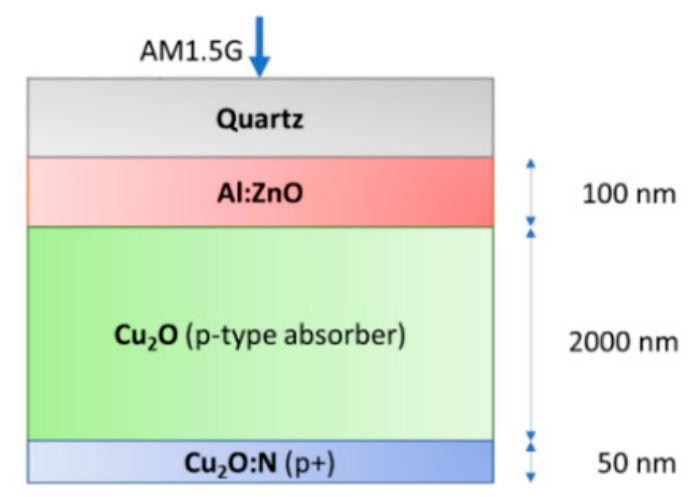

Figure 1. Simplified diagram of the simulated metal oxide solar cell.

\subsection{Electrical Modeling and Simulation Results for the Two Subcells of the Tandem Heterojunction Solar Cell}

Numerical modeling of the metal oxide heterojunction solar cell was developed based on three simulation software packages, namely Silvaco Atlas, MATLAB, and Quokka 2. The tandem heterojunction solar cell was constituted from two subcells: the metal oxide $\left(\mathrm{Cu}_{2} \mathrm{O}\right)$ top subcell and c-Si bottom subcell. The electrical properties of the absorber $\left(\mathrm{Cu}_{2} \mathrm{O}\right)$ and buffer layer $(\mathrm{ZnO})$ from the structure of the top subcell were analyzed using Silvaco Atlas software. The implementation of defects, as well as the study of two efficient materials $\left(\mathrm{ZnO}\right.$ and $\left.\mathrm{Ga}_{2} \mathrm{O}_{3}\right)$ for the buffer layer were investigated [13-17] and several analyses were considered using the Takiguchi model [7]. A transition interface defect layer (IDL) was introduced as well.

Several comparisons using the Silvaco numerical model were discussed. One of the most interesting buffer materials is $\mathrm{ZnO}$ generally, and in particular, the $\mathrm{AZO}$ layer ( $\mathrm{Al}: \mathrm{ZnO})$. This material is very suitable from the point of view of the conduction bandgap offset in regards to $\mathrm{Cu}_{2} \mathrm{O}$. The dependence of the AZO thickness on top cell efficiency is plotted in the Figure 2; the optimum value for the AZO thickness looks to be $0.25 \mu \mathrm{m}$. Further analysis examined (1) the dependence of IDL thickness on top cell efficiency (Figure 3), (2) the impact of buffer electron mobility on subcell fill factor (FF) and efficiency $(\eta)$ (Figure 4), and (3) the impact of buffer and IDL affinity on subcell efficiency $(\eta)$ (Figure 5). We have remarked that a buffer electron mobility value under $100 \mathrm{~cm}^{2} / \mathrm{V} \cdot \mathrm{s}$ would greatly affect the fill factor and efficiency. Defect densities are very important from the practical point of view in order to obtain required performance, especially for absorber and defect layers. We could compare different buffer and IDL materials from the point of view of their affinity. The optimal affinity interval (3.4-3.6 eV) for the buffer layer would determine the lower conduction band offset with the copper oxide absorber layer. The optimal affinity interval for IDL is larger (from 2.95 to $3.4 \mathrm{eV}$ ).

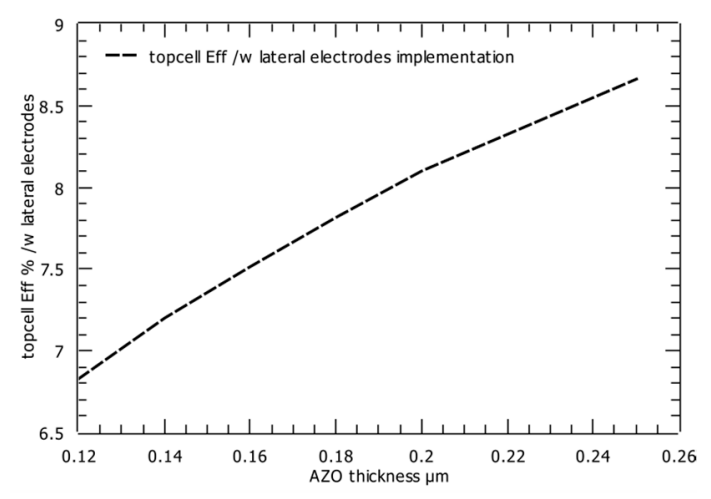

Figure 2. AZO (Al:ZnO) thickness vs. top cell efficiency. 


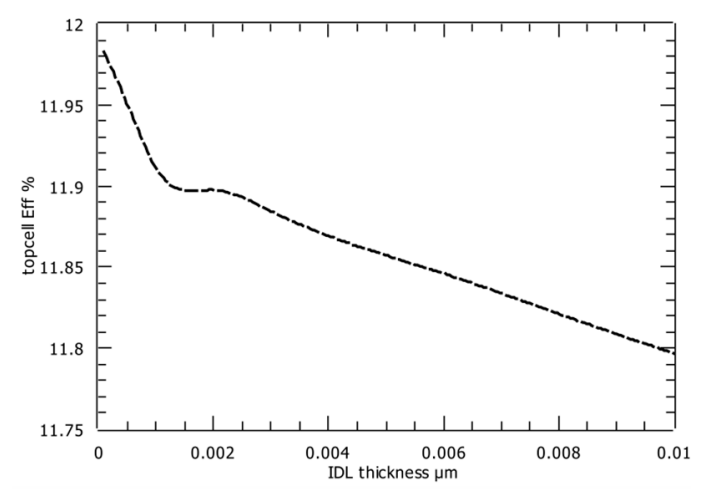

Figure 3. Interface defect layer (IDL) thickness vs. top cell efficiency.

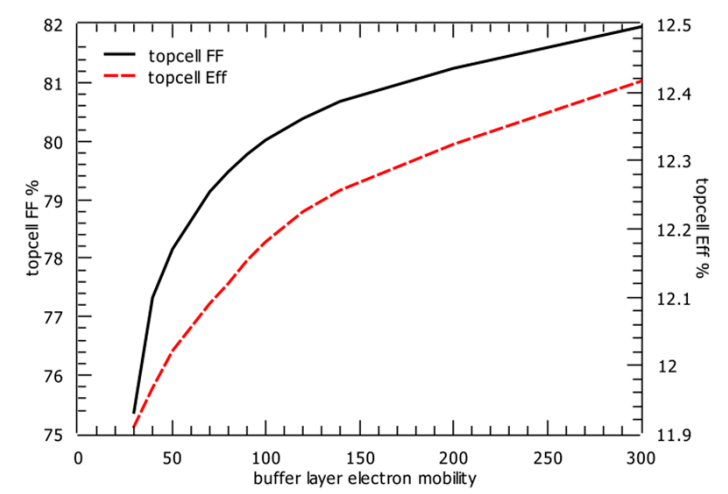

Figure 4. Buffer electron mobility $\left(\mathrm{cm}^{2} / \mathrm{V} \cdot \mathrm{s}\right)$ vs. top subcell fill factor and efficiency.

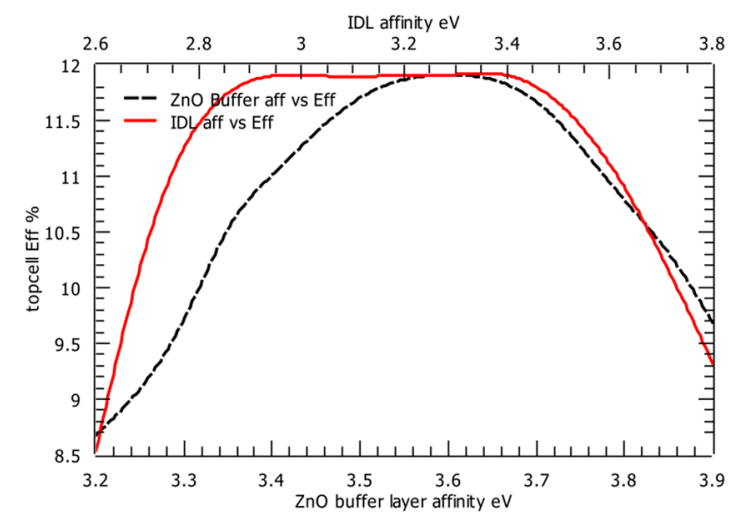

Figure 5. Buffer and IDL affinity vs. subcell efficiency.

A numerical model was adopted using the Quokka 2 software for the bottom subcell. The current-voltage $(\mathrm{J}-\mathrm{V})$ characteristics compared the experimental curve with the numerical modeled one (Figure 6).

The numerical model was used to fit to the experimental curve for control and prediction (Table 1) and to establish the essential electrical parameters for the silicone solar subcell.

A comparison between the experimental graph and Quokka modeled one for EQE (external quantum efficiency) is presented in Figure 7. Further improvement of the model would be required in the interval $750-1000 \mathrm{~nm}$. 


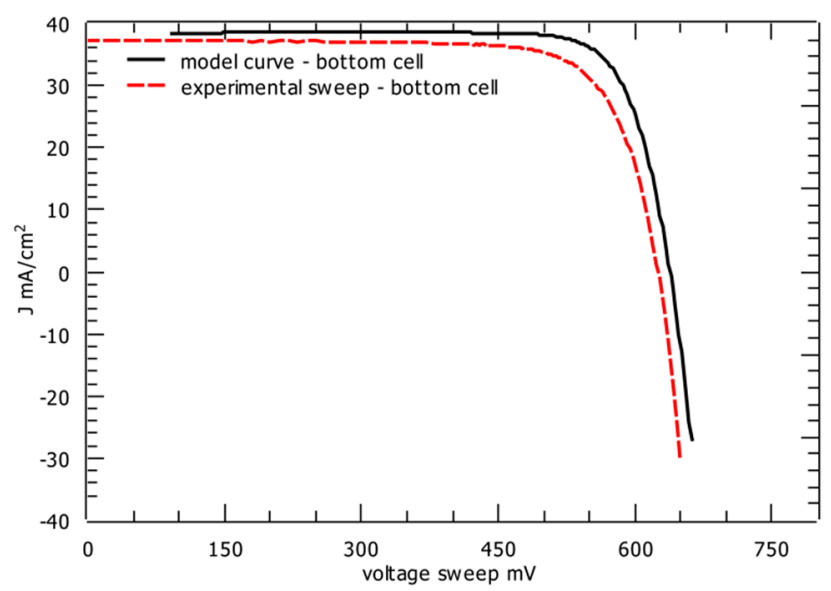

Figure 6. Experimental vs. Quokka 2 modeled J-V curve.

Table 1. Experimental J-V fit parameters for the c-Si subcell.

\begin{tabular}{cc}
\hline Parameter Name & Parameter Value \\
\hline Open circuit voltage, $\mathrm{V}_{\mathrm{OC}}(\mathrm{mV})$ & 625.16 \\
Fill Factor, FF $(\%)$ & 76.83 \\
Series resistance, $\mathrm{R}_{\mathrm{S}}\left(\mathrm{ohm} / \mathrm{cm}^{2}\right):$ & 0.196 \\
Shunt resistance, $\mathrm{R}_{\mathrm{SH}}\left(\mathrm{ohm} / \mathrm{cm}^{2}\right):$ & 2382.8 \\
\hline
\end{tabular}

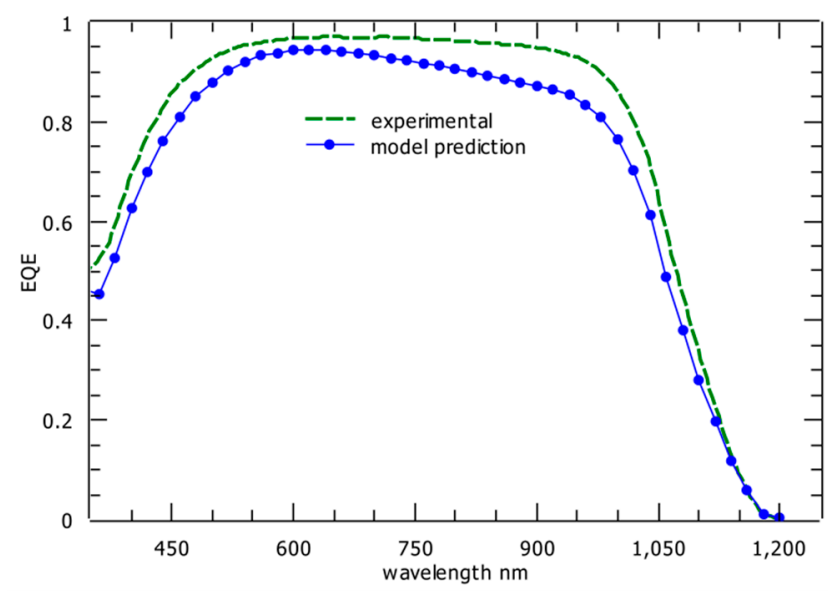

Figure 7. Experimental vs. Quokka modeled external quantum efficiency (EQE) curve.

The rather large current mismatch between the two subcells in tandem configuration, caused by the large band gap difference for the two absorbers, allows for individual optimization of the top and bottom subcells and favors the arrangement of a four-terminal configuration.

That is why it is possible to increase the conversion efficiency of the tandem heterojunction $\mathrm{ZnO} / \mathrm{Cu}_{2} \mathrm{O}$ silicone solar cell beyond the limit of conventional c-Si single-junction solar cell.

\subsection{Optical Modeling and Simulation Results for the Top Subcell}

In order to evaluate the optical characteristics of the device, we have used OPAL 2 software developed by PV (photovoltaic) Lighthouse [18]. OPAL 2 is a fast, reliable, and free online software tool that simulates the optics of advanced solar cells $[19,20]$. The optical modeling was performed for an AM1.5G solar spectrum and with experimentally determined complex refractive indices for the $\mathrm{AZO}$ and $\mathrm{Cu}_{2} \mathrm{O}$ layers. The modeling was performed in the wavelength range from $300 \mathrm{~nm}$ to $800 \mathrm{~nm}$.

Simulated optical functions were the normalized reflectance, absorptance, and transmittance as a function of wavelength for the studied device model, for the samples $1-3$ of $\mathrm{Cu}_{2} \mathrm{O}: \mathrm{N}$, to be discussed 
in the experimental section. The simulations are presented in Figure 8. For these simulations, a $100 \mathrm{~nm}$ thick AZO layer, a $2 \mu \mathrm{m}$ thick $\mathrm{Cu}_{2} \mathrm{O}$ layer, and a $50 \mathrm{~nm}$ thick $\mathrm{Cu}_{2} \mathrm{O}: \mathrm{N}$ layer were implemented in the model. A standard thickness of $50 \mathrm{~nm}$ was set for samples 1-3 of $\mathrm{Cu}_{2} \mathrm{O}: \mathrm{N}$ used in the solar cell structure.

The maximum reflectance in the $575-800 \mathrm{~nm}$ wavelength range for Sample 2 is a bit lower than the maximum values for Samples 1 and 3, as can be seen in Figure 8a. This result could prove useful for reflectance loss optimization.

The absorptance is high for all samples in the $300-525 \mathrm{~nm}$ wavelength range (with an average value of $90 \%$ ). It decreases abruptly in the $525-600 \mathrm{~nm}$ range and tends to low values $(<10 \%)$ in the 600-800 nm range, as seen in Figure 8b.

Transmittance was plotted concurrently for all three samples, as shown in Figure 8c. The transmittance suggests that Samples 1 and 3 yield a better transmission starting from the $560 \mathrm{~nm}$ wavelength. The cutoff wavelengths from the transmittance plot are $595 \mathrm{~nm}, 620 \mathrm{~nm}, 650 \mathrm{~nm}$, $690 \mathrm{~nm}, 730 \mathrm{~nm}, 775 \mathrm{~nm}$, and so on, a periodic spectral pattern being observed. The same approach can be taken for the reflectance plot. For the absorptance plot, the only significant cutoff wavelength is $590 \mathrm{~nm}$. Based on the transmittance data, Tauc plots [20] for Samples 1-3 were calculated and presented in Figure 9.

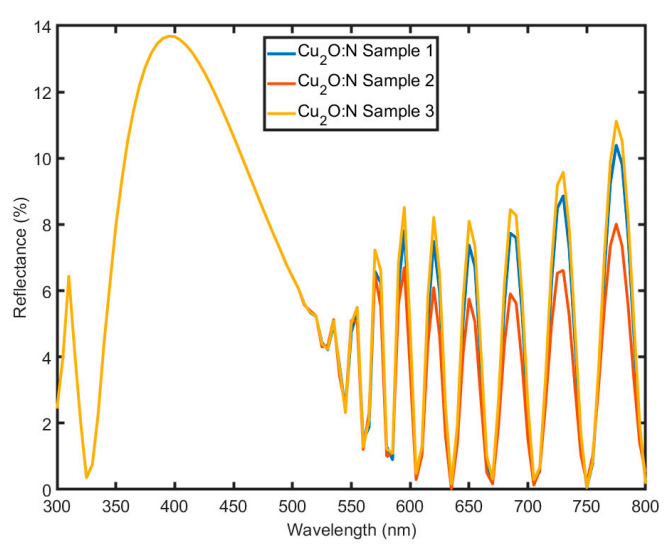

(a)

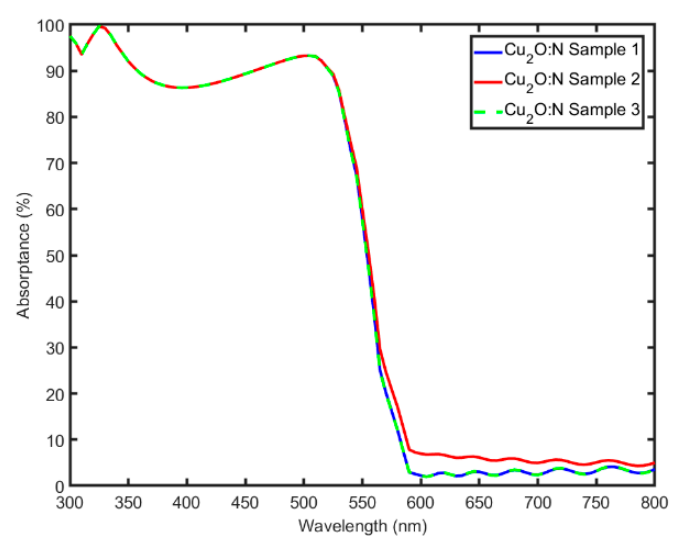

(b)

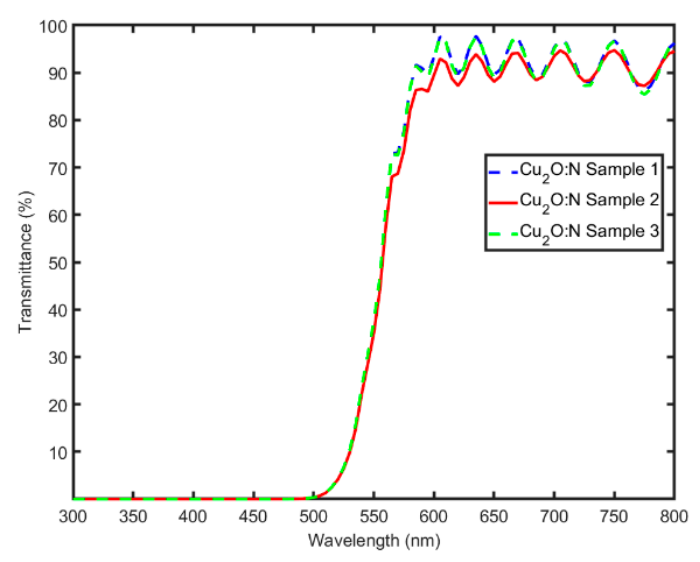

(c)

Figure 8. Percentage (a) reflectance, (b) absorptance, and (c) transmittance as a function of wavelength for the metal oxide structure. 


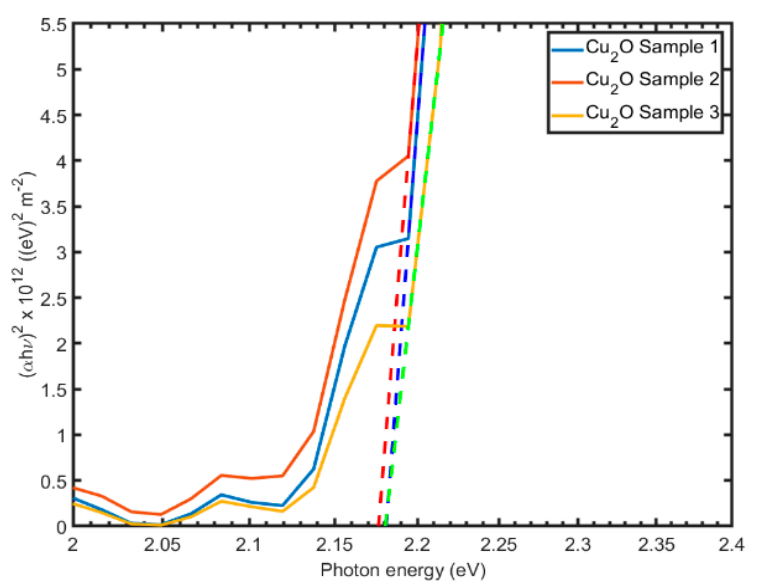

Figure 9. Tauc plots of Samples 1, 2, and 3 deposited on quartz substrate.

Tauc plots indicate an optical bandgap around $2.18 \mathrm{eV}$ for Sample 1, $2.17 \mathrm{eV}$ for Sample 2, and around $2.18 \mathrm{eV}$ for Sample 3, which is in agreement with the ellipsometry measurements (see experimental section).

\subsection{Relevance of the Best Simulation Tools for Numerical Modeling and Optimization of Metal Oxide Solar Devices}

The simulation methodology could be used for design and material performance optimization. Two simulators were considered to be the best for the two subcells; Silvaco is the optimum tool for the top metal oxide solar subcell and absorbs the high energy part of sunlight, while PC1D is the most efficient tool for the bottom silicone solar subcell and absorbs the low energy part of sunlight. The simulated device with optimized parameters could be validated by comparing the numerical modeled results and performance with the experimental ones offered by an industrial manufactured solar cell with identical parameters.

\section{Experimental Investigation of $\mathrm{N}$-Doped $\mathrm{Cu}_{2} \mathrm{O}$ Absorber Layer}

\section{1. $\mathrm{Cu}_{2} \mathrm{O}$ Thin Film Fabrication and Overall Characterization}

$\mathrm{Cu}_{2} \mathrm{O}$ thin films were deposited on quartz substrates by direct current (DC) magnetron sputtering system (Semicore Triaxis) on $1 \mathrm{~cm} \times 1 \mathrm{~cm}$ quartz substrates at $400{ }^{\circ} \mathrm{C}$ by varying the $\mathrm{N}_{2}$ and $\mathrm{Ar} / \mathrm{O}_{2}$ flow [21]. Samples 1 and 2 were deposited at $400{ }^{\circ} \mathrm{C}$ with nitrogen flows 1 and $3 \mathrm{sccm}$ (standard cubic centimeters per minute), respectively, while the $\mathrm{Ar} / \mathrm{O}_{2}$ flow was maintained constant. Sample 3 was deposited at $400{ }^{\circ} \mathrm{C}$ with $\mathrm{Ar} / \mathrm{N}_{2}$ flow of $1 \mathrm{sccm}$ while the $\mathrm{O}_{2}$ flow was fixed. The pre-sputtering time was $15 \mathrm{~min}$, to avoid any contamination. The quartz substrates were cleaned in piranha solution and rinsed in deionized water, blown dry with nitrogen, and loaded into the deposition chamber. The same deposition time was used for all samples. The deposition power was fixed at $100 \mathrm{~W}$. The base pressure before deposition was below $5 \times 10^{-7}$ Torr while the sample stage was rotated at a constant speed of $12 \mathrm{rpm}$ during deposition. The Hall effect measurements (LakeShore 7604) using the van der Pauw method were carried out to determine the hole mobility, resistivity, and hole carrier density.

The hole carrier density of as-deposited Sample 0 is $\sim 10^{15} \mathrm{~cm}^{-3}$ with low mobility $\left(\sim 13 \mathrm{~cm}^{2} / \mathrm{Vs}\right)$ and resistivity $(\sim 200 \Omega \mathrm{cm})$, respectively. The hole carrier density for Samples 1 and 2 varied from $\sim 10^{17}-10^{19} \mathrm{~cm}^{-3}$ with low carrier mobility $\left(\sim 0.1-1 \mathrm{~cm}^{2} / \mathrm{Vs}\right)$ and resistivity $(3-13 \Omega \mathrm{cm})$, respectively, while Sample 3 has carrier density $\sim 10^{16} \mathrm{~cm}^{-3}$ with resistivity $\sim 54 \Omega \mathrm{cm}$ and carrier mobility $\sim 1.5 \mathrm{~cm}^{2} / \mathrm{Vs}$. A reduced resistivity was achieved in the $\mathrm{N}$-doped samples $(1,2$, and 3$)$ compared to the undoped Sample 0. This may reflect the presence of $\mathrm{N}$ in the $\mathrm{DC} \mathrm{Cu}_{2} \mathrm{O}$ film magnetron sputtering process influencing the electrical characteristics of solar cell as mentioned previously. 
The process characteristics and layer structure of $\mathrm{Cu}_{2} \mathrm{O}: \mathrm{N}$ thin film samples, deposited by DC magnetron sputtering on quartz substrate, are presented in Table 2.

Table 2. Process characteristics and layer structure of $\mathrm{Cu}_{2} \mathrm{O}: \mathrm{N}$ thin films.

\begin{tabular}{ccc}
\hline Sample Name & Gas Flow Conditions & Grains Size (nm) \\
\hline Sample 0 & $\mathrm{Ar} / \mathrm{O}_{2}$ was fixed at $42.5 / 7.5 \mathrm{sccm}$ & $20-90$ \\
Sample 1 & $\left(\mathrm{Ar} / \mathrm{O}_{2}\right.$ was fixed $\left.1 \mathrm{sccm} 42.5 / 7.5 \mathrm{sccm}\right)$ & $20-48$ \\
Sample 2 & $\left(\mathrm{Ar} / \mathrm{O}_{2}\right.$ was fixed $\left.3 \mathrm{sccm} 42.5 / 7.5 \mathrm{sccm}\right)$ & $30-54$ \\
& N-doped $1 \mathrm{sccm}$ \\
Sample 3 & $\left(\right.$ Ar was varied at $41.5 \mathrm{sccm}, \mathrm{O}_{2}$ & $40-88$ \\
& was fixed at $7.5 \mathrm{sccm})$ & \\
\hline
\end{tabular}

\subsection{Morphological and Structural Characterization of the $\mathrm{Cu}_{2} \mathrm{O}: \mathrm{N}$ Films}

The surface morphology of the $\mathrm{Cu}_{2} \mathrm{O}: \mathrm{N}$ thin films was studied by SEM with the Quanta Inspect F 50 scanning electron microscope. Topographic AFM imaging was also performed by AFM with the Veeco Innova atomic force microscope, in the tapping mode, with $2.5 \mu \mathrm{m} / \mathrm{s}$ scanning speed. AFM images have a resolution of $512 \times 512$ pixels. The software used for image analysis was SPM Lab Analysis v.7.0 (Version 7.0, Veeco Innova, Bruker-Milton, ON, Canada, Santa Barbara-CA, USA.)

\subsubsection{Scanning Electron Microscopy (SEM)}

Experimental measurements for the determination of surface morphology were performed on $\mathrm{Cu}_{2} \mathrm{O}: \mathrm{N}$ thin films deposited by the $\mathrm{DC}$ magnetron sputtering on the quartz substrate under different gas flow conditions. Figure 10 shows the SEM images of four samples (see Table 2): one undoped $\mathrm{Cu}_{2} \mathrm{O}$ film (Sample 0) and three $\mathrm{Cu}_{2} \mathrm{O}: \mathrm{N}$ thin film samples (Samples 1-3).

The grain size in the deposited layers is listed in Table 2 and compared with undoped $\mathrm{Cu}_{2} \mathrm{O}$ film (Sample 0 ). With the increase of the $\mathrm{N}_{2}$ flow, the films display a uniform layer surface with larger particle size (Samples 1 and 2). A varied Ar pressure induces a non-uniform particle size distribution (Samples 1 and 3). The particle size distribution of the undoped $\mathrm{Cu}_{2} \mathrm{O}$ layer is non-uniformly distributed in the range $20-90 \mathrm{~nm}$. As result, the presence of $\mathrm{N}_{2}$ and an $\mathrm{Ar} / \mathrm{O}_{2}$ fixed flow improves the size uniformity of the deposited $\mathrm{Cu}_{2} \mathrm{O}$ layers.
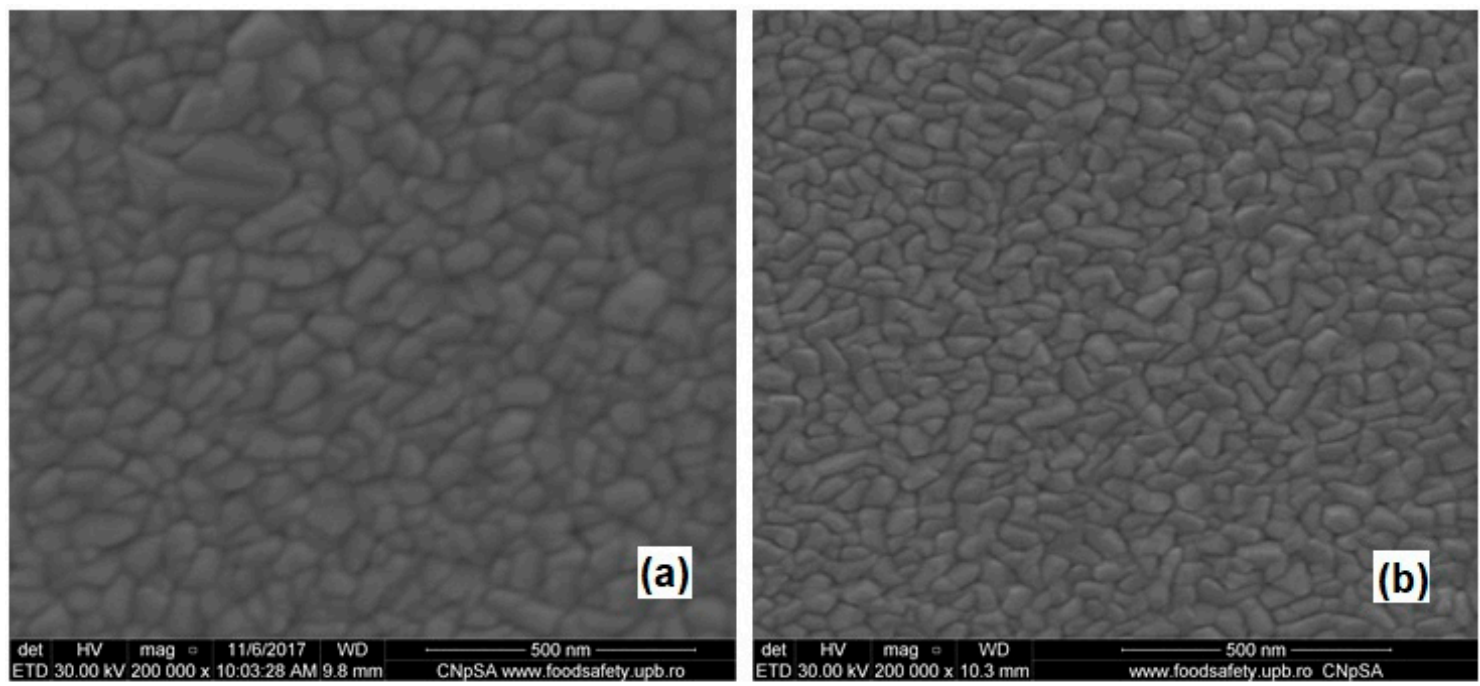

Figure 10. Cont. 

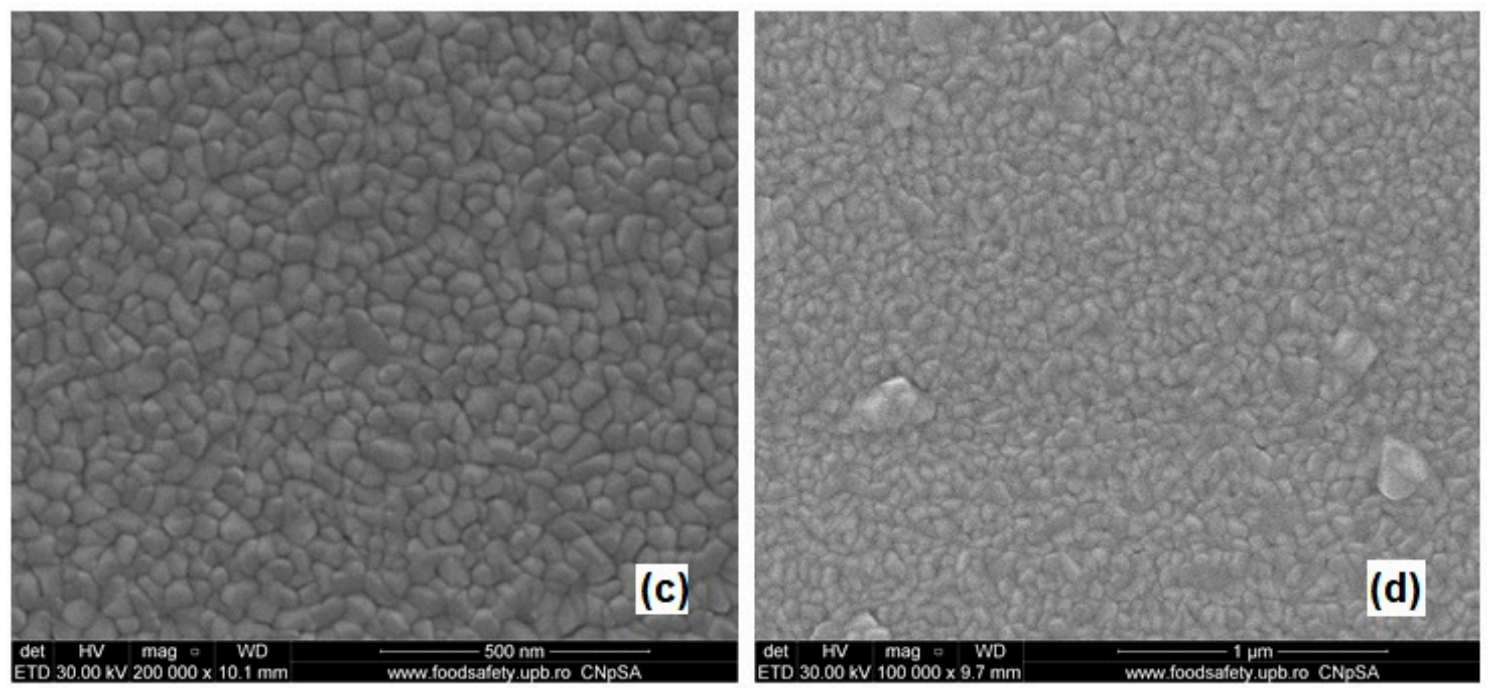

Figure 10. SEM images of $\mathrm{Cu}_{2} \mathrm{O}$ thin films deposited on quartz substrate: (a) Sample 0, (b) Sample 1, (c) Sample 2, and (d) Sample 3.

\subsubsection{Atomic Force Microscopy (AFM)}

The grain size, including surface roughness of $\mathrm{Cu}_{2} \mathrm{O}: \mathrm{N}$ thin film deposited on quartz substrate, was measured by topographic AFM imaging. The surface morphologies for each of the $\mathrm{N}$-doped thin film samples compared with Sample 0 are shown in Figure 11 as 2D AFM images, along with their corresponding surface profile histograms, and in Figure 12 as 3D AFM images. The root-mean-square surface roughness $\left(R_{\mathrm{RMS}}\right)$ for each sample was extracted from their AFM images [22,23].

The histograms represent the statistical distribution of the height surface profile of the $\mathrm{Cu}_{2} \mathrm{O}$ samples derived from the AFM images and show a higher distribution in the first half of the height range for Samples 1 and 2. However, the height profile distribution of Sample 3 shows less roughness. This is related to the deposition conditions and in accordance with the $R_{R M S}$ parameter calculations in Table 3, which shows a lower $R_{R M S}$ for this sample. According to the statistical distribution of the surface height profile, Samples 1, 2, and 3 have the highest frequency at a surface height of $26 \mathrm{~nm}$, $25 \mathrm{~nm}$, and $17 \mathrm{~nm}$, respectively. For validation, $R_{R M S}$ was derived from the histograms based on the 2D AFM images, processed in MATLAB, and presented in Table 3.

Table 3. $R_{R M S}$ of $\mathrm{Cu}_{2} \mathrm{O}$ thin films and height distribution standard deviation, derived from histograms of 2D AFM images.

\begin{tabular}{ccc}
\hline Sample Deposited on Quartz & $\begin{array}{c}\boldsymbol{R}_{\boldsymbol{R} M S} \\
(\mathbf{n m})\end{array}$ & Height Distribution Standard Deviation (nm) \\
\hline Sample 0 & 6.3 & 7.8 \\
Sample 1 & 4.7 & 5.8 \\
Sample 2 & 4.2 & 4.5 \\
Sample 3 & 3.9 & 4.2 \\
\hline
\end{tabular}

According to Table 3 , the roughness deviation values follow the same trend as the $R_{R M S}$ values, where Sample 1 has the highest deviation and Sample 3 presents the lowest one. Additionally, the undoped $\mathrm{Cu}_{2} \mathrm{O}$ film (Sample 0) presents a greater roughness than the doped Samples 1-3. 

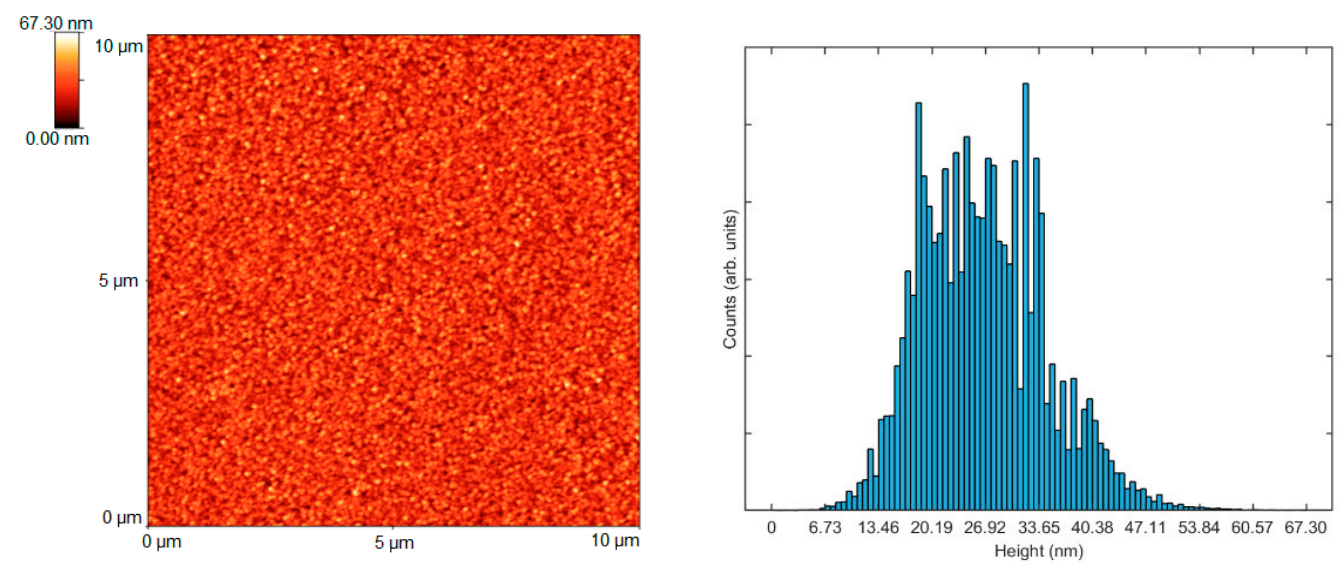

Sample 0
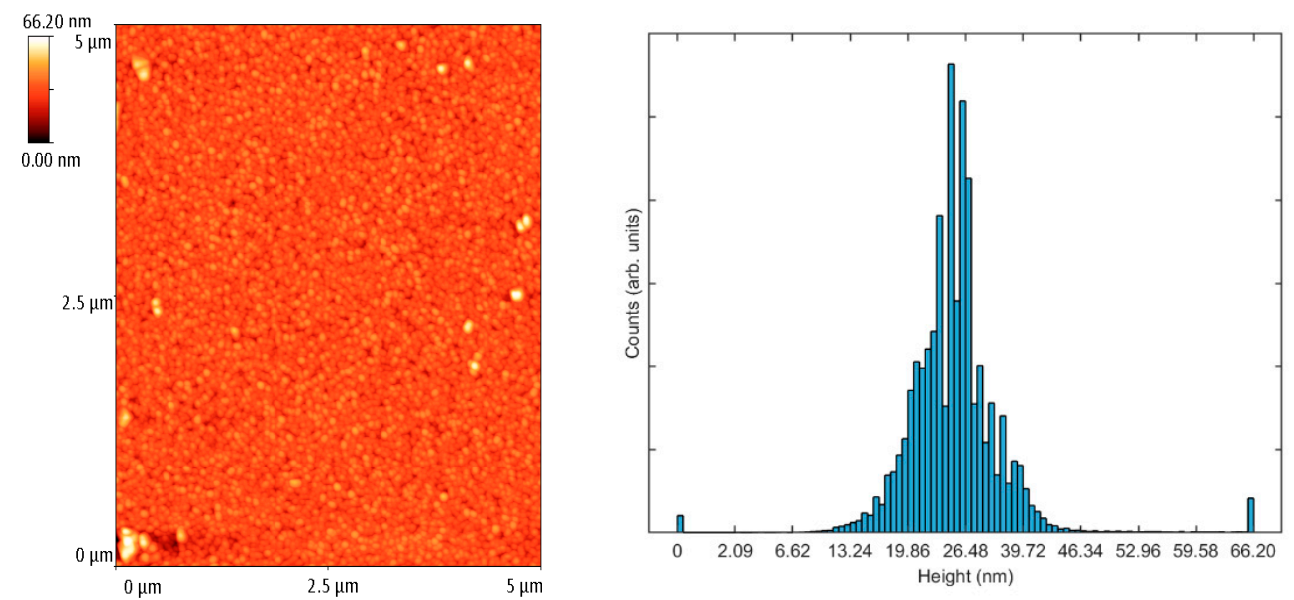

Sample 1
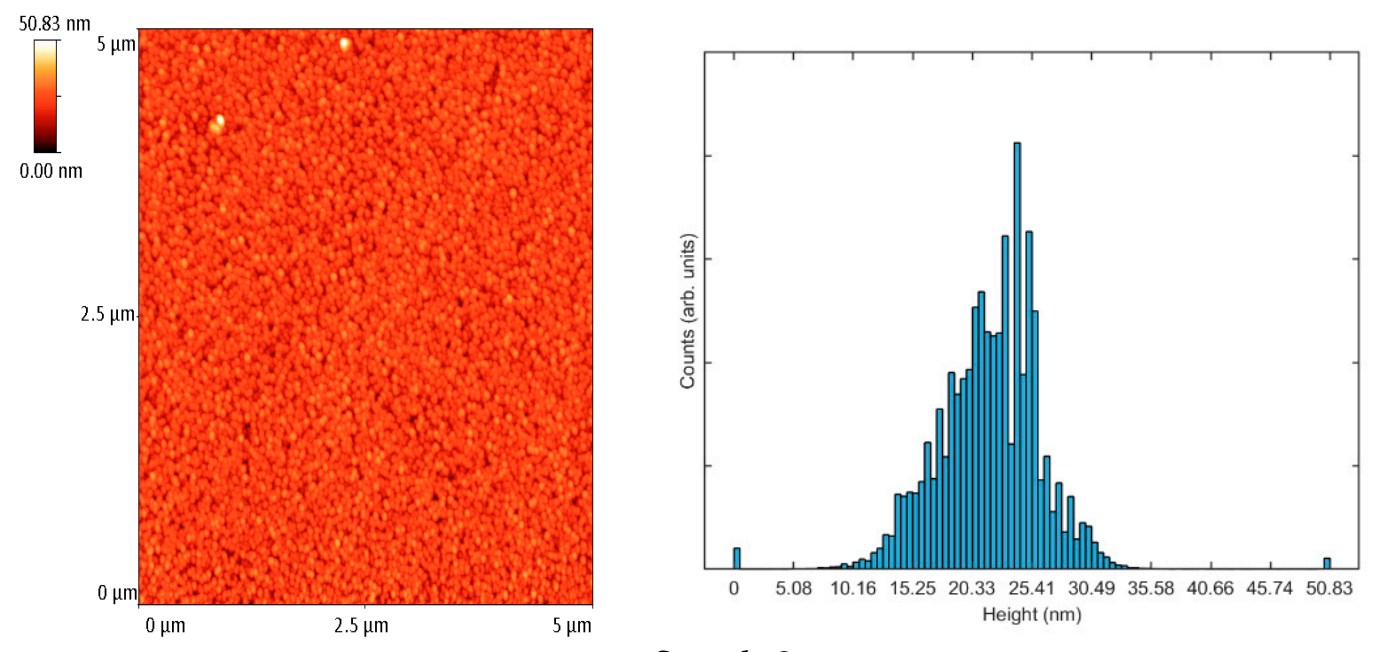

Sample 2

Figure 11. Cont. 

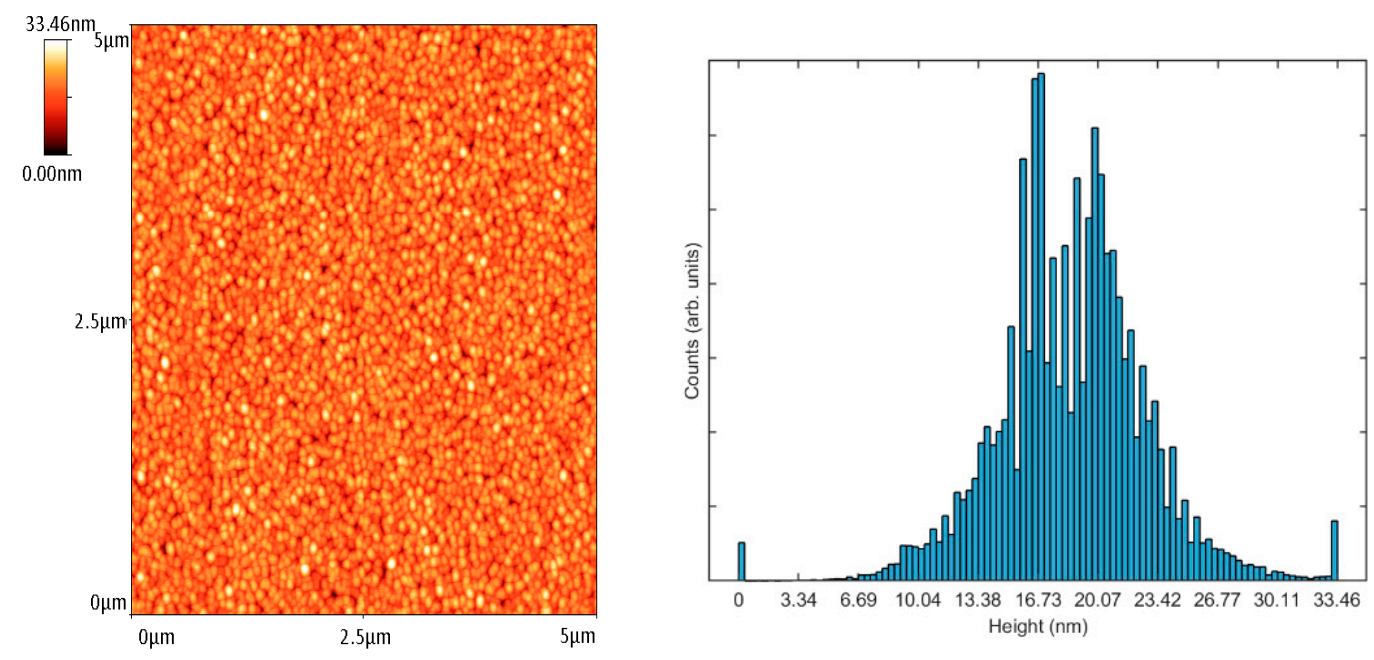

Sample 3

Figure 11. 2D AFM images of Samples 0-3 and their corresponding histograms.

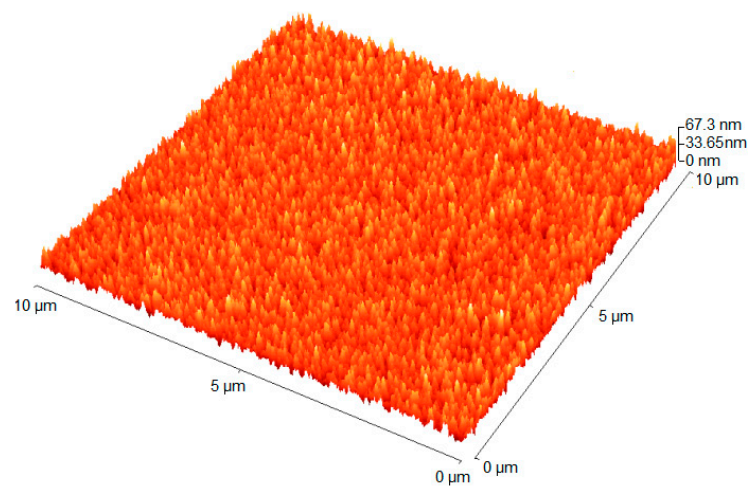

Sample 0

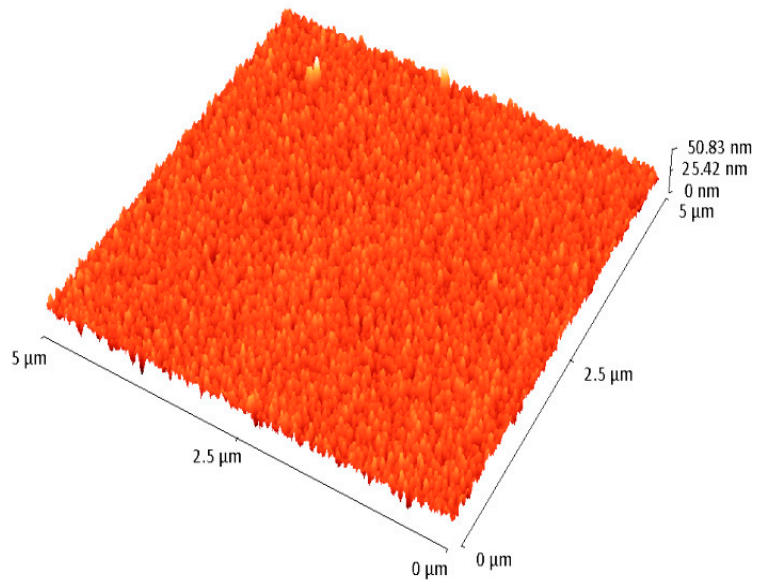

Sample 2

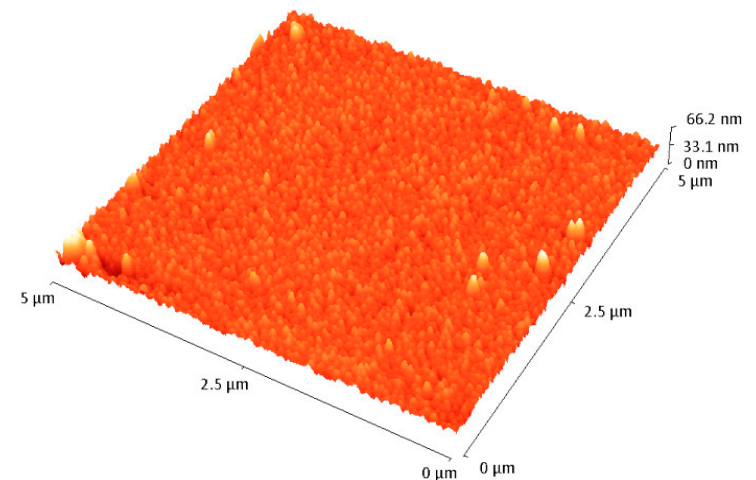

Sample 1

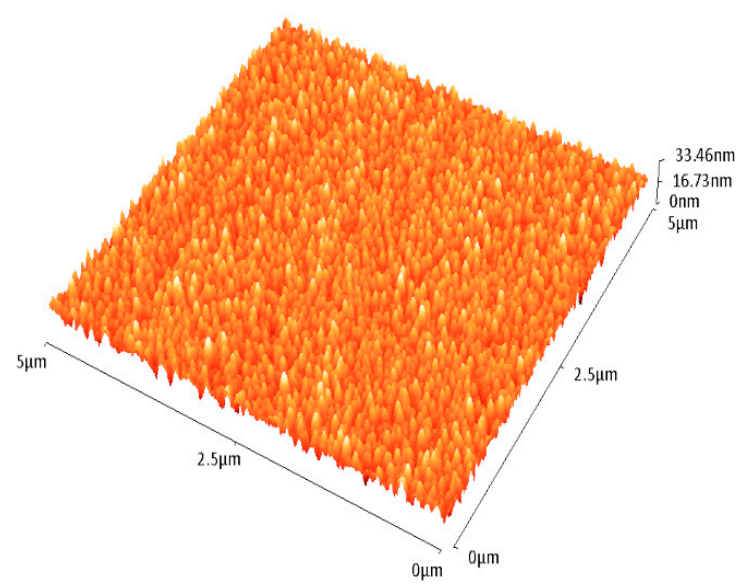

Sample 3

Figure 12. 3D AFM images of Samples 0-3.

\subsubsection{Structural Characterization by XRD}

The XRD pattern was obtained by a Bruker AXS D8 Discover Diffractometer, using $\mathrm{Cu} K \alpha$-radiation and a Bragg-Brentano configuration. The background and $K \alpha 2$ were stripped from the XRDs using the EVA software. The dominant XRD peaks were recorded in 2-theta range from 30-60. 
Figure 13 displays the XRD patterns of all samples, recorded in the range $30-60^{\circ}$. XRD patterns show that all films were dominated by a (200) reflection peak at $42.61^{\circ}$ and a (111) reflection peak corresponding to $36.45^{\circ}$. The XRD pattern is not significantly influenced by nitrogen doping [24]. The $\mathrm{Cu}_{2} \mathrm{O}$ peaks were determined by comparing experimental XRD peak patterns with the standard Powder Diffraction cards (ICDD patterns: 01-071-3645) [25].

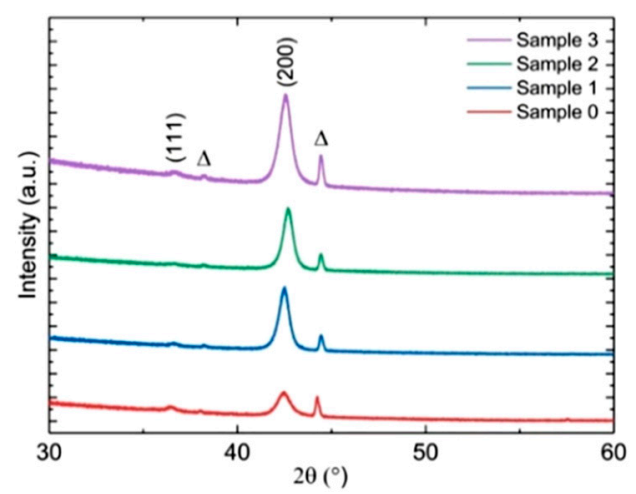

Figure 13. XRD patterns of Samples $0-3$ in the range $30-60^{\circ}$, where $\Delta$ represents the background peak.

XRD patterns of the $\mathrm{Cu}_{2} \mathrm{O}: \mathrm{N}$ films prepared under various $\mathrm{N}_{2}$ flow rates, together with the data of the $\mathrm{Cu}_{2} \mathrm{O}$ reference films, show highly oriented (111) planes. For the $\mathrm{Cu}_{2} \mathrm{O}: \mathrm{N}$ samples, the peak intensity of the (111) plane decreases significantly with increasing of $\mathrm{N}_{2}$ flow rate, and (200) planes show up in the heavy $\mathrm{N}$-doping range [26].

\subsection{Optical Characterization}

Optical characterization involved two tools: FTIR spectroscopy and spectroscopic ellipsometry. FTIR spectroscopy analysis was carried out using a Perkin Elmer type Spectrum 100 spectrometer, with UATR accessory-PIKE GladiATR, in the wavenumber range $430-2000 \mathrm{~cm}^{-1}$ with a spectral resolution of $0.4 \mathrm{~cm}^{-1}$. The refractive index and extinction coefficient of $\mathrm{Cu}_{2} \mathrm{O}: \mathrm{N}$ thin film were determined by spectroscopic ellipsometry, in the wavelength range from 190 to $2100 \mathrm{~nm}$ using an UVISEL spectroscopic ellipsometer from HORIBA Jobin Yvon. A model fit to the measured ellipsometry parameters was obtained using DeltaPsi 2.6 software (Version 2.6, HORIBA, Jobin Yvon, Palaiseau, France).

\subsubsection{FTIR Spectroscopy}

The FTIR transmission spectra obtained for $\mathrm{Cu}_{2} \mathrm{O}: \mathrm{N}$ thin films are shown in Figure 14 and the transmission peaks are listed in Table 4.

Table 4. Transmission peaks for $\mathrm{Cu}_{2} \mathrm{O}: \mathrm{N}$ thin films.

\begin{tabular}{cc}
\hline Sample Name & $\boldsymbol{v} \mathbf{C u}_{\mathbf{2}} \mathbf{O}\left(\mathbf{c m}^{-\mathbf{1}}\right)$ \\
\hline Sample 1 & 608 \\
Sample 2 & 616 \\
Sample 3 & 615 \\
\hline
\end{tabular}




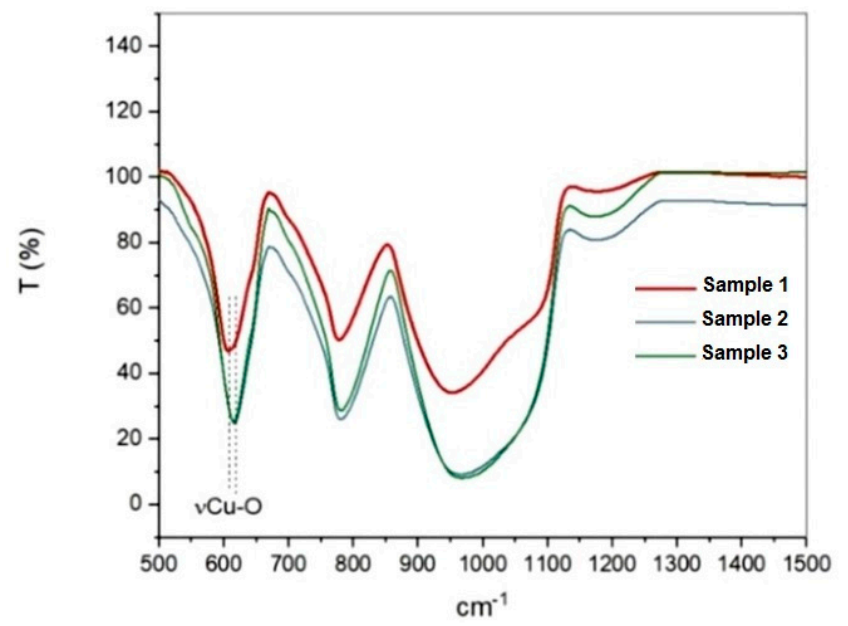

Figure 14. FTIR transmission spectra for $\mathrm{Cu}_{2} \mathrm{O}: \mathrm{N}$ thin film: Sample 1, Sample 2, and Sample 3.

The FTIR spectra of all samples deposited on quartz displayed the peaks corresponding to the vibrational modes of Si-O belonging to the quartz substrate $\left(780 \mathrm{~cm}^{-1}\right.$, broadband centered at $980 \mathrm{~cm}^{-1}$ with a shoulder at $\left.1080 \mathrm{~cm}^{-1}\right)[26,27]$. The band located at $608-616 \mathrm{~cm}^{-1}$ corresponds to the stretching vibrational mode of $\mathrm{Cu}-\mathrm{O}$ in $\mathrm{Cu}_{2} \mathrm{O}$ phase. There is an increasing trend in the intensity of the $\mathrm{Cu}-\mathrm{O}$ absorption band from Sample 1 to Sample 3, suggesting an increased concentration of $\mathrm{N}_{2}$. This result is in agreement with the recent theoretical predictions that nitrogen mainly substitutes $\mathrm{Cu}$ in the molecular form, $\left(\mathrm{N}_{2}\right) \mathrm{Cu}$, in $\mathrm{N}$-doped $\mathrm{Cu}_{2} \mathrm{O}$ rather than as substitutional $\mathrm{N}$ on the $\mathrm{O}$ site, (NO) [5]. The decrease in resistivity, coherently with the increase in $\mathrm{N}$ doping concentration, was explained by annealing-driven substitution of oxygen atoms with implanted $\mathrm{N}$ atoms. The $\mathrm{N}$ doping may induce any definite variation in energy band structure of $\mathrm{Cu}_{2} \mathrm{O}$ films [25].

In general, the photoluminescence (PL) spectra of $\mathrm{Cu}_{2} \mathrm{O}$ films contain two main signals ranging from 450 to $650 \mathrm{~nm}$, which are considered to be derived from free excitons and the bound excitonic region [28].

\subsubsection{Spectroscopic Ellipsometry (SE)}

The ellipsometry parameters of $\mathrm{Cu}_{2} \mathrm{O}: \mathrm{N}$ thin films deposited on quartz substrate were investigated with a resolution of 27 points in the range $1.5-4.1 \mathrm{eV}$ (with step $0.1 \mathrm{eV}$ ). The investigated parameters were the band gap and the surface roughness $[29,30]$ and were listed in Table 5.

Table 5. Investigated (SE) parameters of $\mathrm{Cu}_{2} \mathrm{O}: \mathrm{N}$ thin films.

\begin{tabular}{cccc}
\hline Sample Name & Sample 1 & Sample 2 & Sample 3 \\
\hline Band gap $(\mathrm{eV}):$ & 2.17 & 2.14 & 2.17 \\
Surface roughness $(\mathrm{nm}):$ & 15.9 & 19.6 & 17.2 \\
\hline
\end{tabular}

By the Tauc-Lorentz oscillator methodology [31], modeling was performed to determine the band gap, surface roughness, refractive index $(n)$, and the extinction coefficient $(k)$ in the range $300-800 \mathrm{~nm}$ (from visible to near infrared) for $\mathrm{Cu}_{2} \mathrm{O}$ thin films deposited on quartz substrates.

The model described a layer of $\mathrm{Cu}_{2} \mathrm{O}$ deposited on the quartz substrate with a hard surface layer. The surface roughness was modeled by mixing the optical constants of the $\mathrm{Cu}_{2} \mathrm{O}$ material surface and the air voids (on average, $90 \% \mathrm{Cu}_{2} \mathrm{O}$ and $10 \%$ air voids).

It is noticed that the surface roughness of $\mathrm{Cu}_{2} \mathrm{O}$ film increases with the level of $\mathrm{N}_{2}$ pressure (Sample 1 and Sample 3 vs. Sample 2), from $15.9 \mathrm{~nm}$ to $19.6 \mathrm{~nm}$ (Table 5). 
The presence of $\mathrm{N}_{2}$ during deposition of $\mathrm{Cu}_{2} \mathrm{O}$ films on quartz substrate produces small changes over $\mathrm{n}$ and $\mathrm{k}$ in the range 300-600 $\mathrm{nm}$ for Samples 1-3 and 300-400 nm for Sample 2, as can be seen in Figure 15.

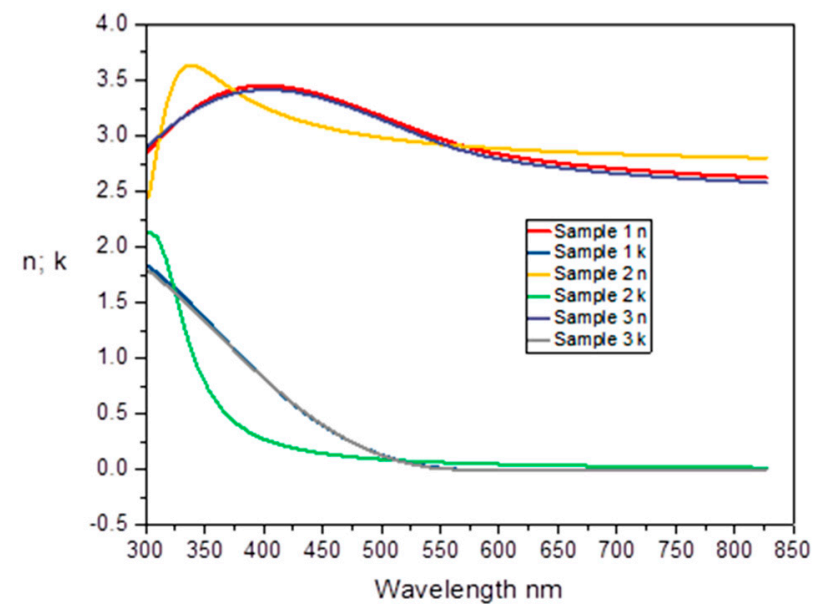

Figure 15. Graphs of $n$ and $k$ coefficients for Samples 1,2 , and 3 of $\mathrm{Cu}_{2} \mathrm{O}: \mathrm{N}$ thin films; $\lambda$ is wavelength.

The changes of $n(\lambda)$ (yellow curve) and $k(\lambda)$ (green curve) coefficients observed in Figure 15 for Sample 2 (the highest $\mathrm{N}$-doped sample) are associated with a structural change in $\mathrm{Cu}_{2} \mathrm{O}$ induced by nitrogen doping. This can be a promising method for modifying the optical properties of the metal oxide [28,32] The crystal size decreases from approximately $23 \mathrm{~nm}$ to approximately $15 \mathrm{~nm}$ with increasing the $\mathrm{N}$-doping concentration in the small $\mathrm{N}$-doping range, where as it is almost unchanged $(18-20 \mathrm{~nm})$ in the heavy $\mathrm{N}$-doping range [26].

For example, undoped $\mathrm{Cu}_{2} \mathrm{O}$ films were deposited on quartz substrates by the RF magnetron sputtering system with a $\mathrm{Cu}_{2} \mathrm{O}$ target $(99.99 \%$, purity); with the $\mathrm{Ar}$ flow rate at $20 \mathrm{sccm}$, the average transmittances in the visible range were $40-60 \%$, and the band gap of $\mathrm{Cu}_{2} \mathrm{O}$ films was approx. $18 \mathrm{eV}$ [29].

\subsection{General Comments on Experimental Investigation and Prospects of Heterojunction Cuprous Oxide Solar} Cells with Nitrogen

The experimental investigation of $\mathrm{N}$-doped $\mathrm{Cu}_{2} \mathrm{O}$ thin films show they have good potential as an absorber layer for photovoltaic applications:

- The doped samples are characterized by higher whole carrier densities, lower carrier mobilities, and lower resistivities in comparison with the undoped sample;

- The SEM images showed the improvement in the size uniformity of the deposited $\mathrm{Cu}_{2} \mathrm{O}$ layers due to $\mathrm{N}$ presence;

- The AFM measurements determined that the roughness is slightly influenced by the $\mathrm{N}$ doping, which could affect the electrical properties of solar cells. The histograms derived from the AFM images showed the surface profile height for the studied $\mathrm{Cu}_{2} \mathrm{O}: \mathrm{N}$ samples and emphasized their roughness deviation;

- The X-ray analysis of $\mathrm{Cu}_{2} \mathrm{O}$ films put in evidence that all such films are polycrystalline and nitrogen doping does not show any significant change in the XRD pattern. A reduced resistivity was achieved in the N-doped samples compared to the undoped sample;

- $\quad$ The FTIR spectra of the samples displayed peaks corresponding to the vibrational modes of Si-O belonging to the quartz substrate;

- The SE analysis stressed the $\mathrm{N}$ influence over the optical properties of the $\mathrm{Cu}_{2} \mathrm{O}$ thin films. The changes of refraction and extinction coefficients were given by the $\mathrm{Cu}_{2} \mathrm{O}: \mathrm{N}$ thin films associated with the structural change in $\mathrm{Cu}_{2} \mathrm{O}$ induced by $\mathrm{N}$-doping. 
At the same time, it could be remarked that the N-doping can lead to the following on the heterojunction copper oxide solar cells with nitrogen:

- regulation of the band gap enabling increased transmittance;

- improved carrier lifetime and transport;

- $\quad$ increased conversion efficiency of the solar cell device.

All these results highlight the $\mathrm{N}$-doped cuprous oxide heterojunction solar cell as a promising candidate for high efficiency solar devices.

\section{Reliability Study}

\subsection{Methodological Tools}

Definition of solar cell reliability: probability of device performance to fit to specific performance parameters for clear operational conditions without deviation outside determined tolerance limits.

There are different accelerated tests to be done regarding the reliability of a solar cell:

(1) Qualitative accelerated test: offers information regarding the solar cell malfunctions or failure ways;

(2) High accelerated life test (HALT) offers information regarding the solar cell failure mechanisms and average lifetime;

(3) High accelerated stress screening (HASS) offers information regarding the solar cell operating time and failure rate within the operating temperature range

In order to perform an accurate reliability analysis of the solar cell, the SYNTHESIS simulation tools developed by ReliaSoft company [33] were used, namely: (1) the Weibull++ tools, which performs life data analysis using multiple lifetime repartitions with a reliability-oriented interface; (2) the ALTA tool, which allows a quantitative analysis of accelerated life tests.

\subsection{Solar Cells Thermal Stability Characteristics}

Three main parameters can be studied using the Weibull statistical repartition: (1) the solar cell lifetime in different conditions: (2) the degradation degree based on the temperature influence; and (3) number of defects (failures).

In order to make the most accurate predictions for the lifetime of the analyzed solar cells, the Weibull statistical repartition method (Figure 16a) of the Weibull++ tool was employed [33].

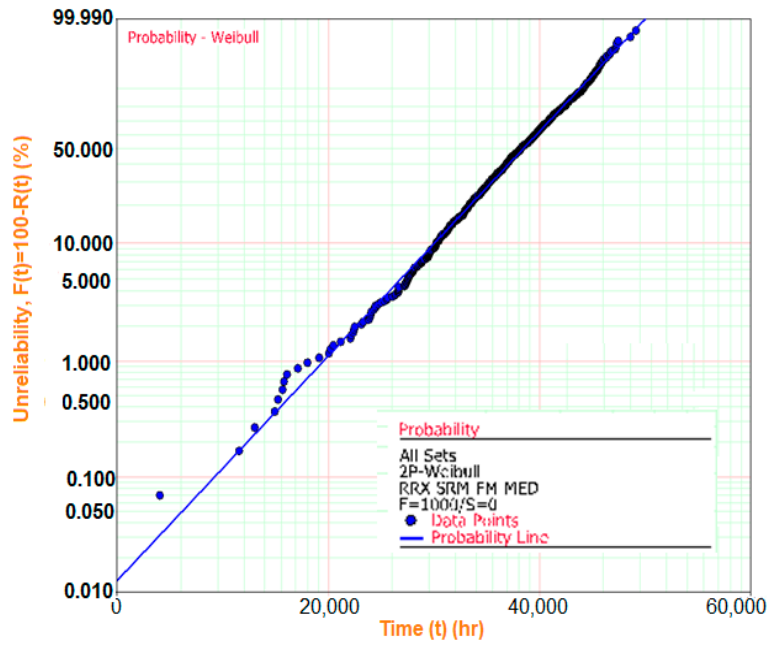

(a)

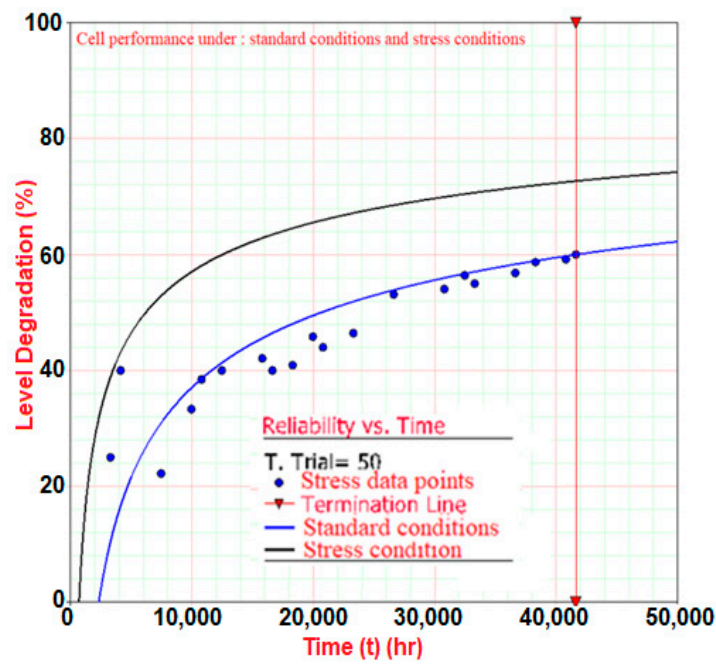

(b)

Figure 16. (a) Weibull distribution for the studied solar cell lifetime; (b) solar cell performance and degradation degree of the analyzed solar cell under standard and stress conditions. 
The degradation degree of the analyzed solar cell can be characterized by the temperature influence on the device [34-36] and is obtained for two cases: (1) under stress conditions (black curve) and (2) under standard conditions (blue curve) (Figure 16b).

Based on the stress results of the HASS test presented in Figure 16b, it is possible to determine, by numerical simulation using the ALTA tool, the limiting value of specific solar cell operating time in normal conditions, as seen in Figure 17a. The HASS test also establishes the probable rate of solar cell failure within the operation temperature range of $50-100{ }^{\circ} \mathrm{C}$ (Figure $17 \mathrm{~b}$ ). It is remarked that the expected failures rate dependence increases strongly with temperature.

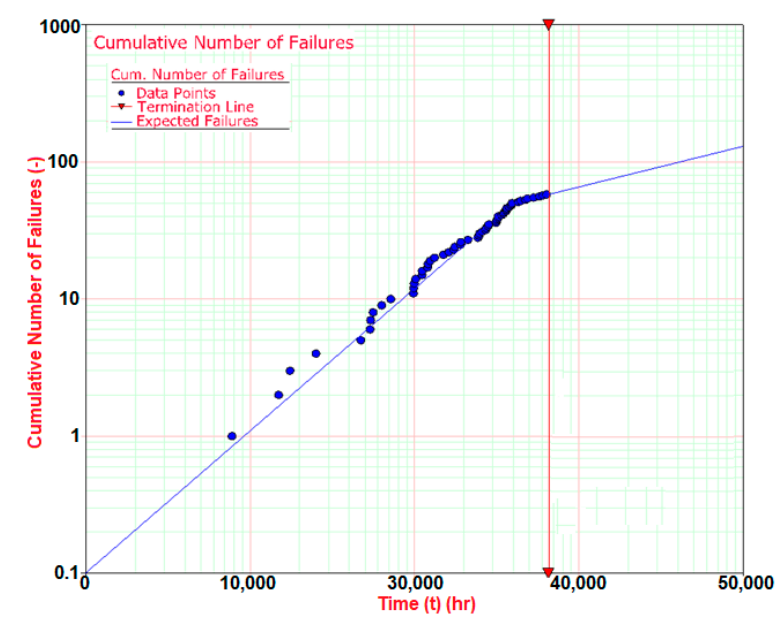

(a)

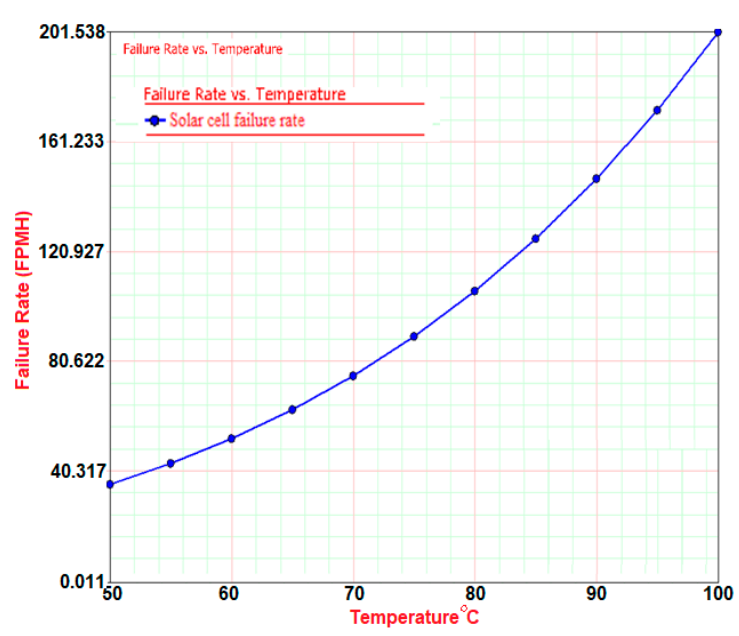

(b)

Figure 17. (a) Cumulative number of failures as function of time (using ALTA module). (b) Baseline survival of solar cell simulation (using ALTA module) in temperature and stress conditions.

The simulated results obtained from this reliability analysis consist both in identifying the solar cell failure modes, as well as to predict the solar cell lifetime in normal operation conditions. At the same time, these simulations enable evaluation of the degradation time and number of defects for the analyzed solar cell. The number of defects increases alarmingly starting at 20,000 operating hours, and by the end of the accelerated HASS test, the solar device would fail (Figure 17a).

\subsection{Further Work}

The simulation tools used in this work, namely Weibull++ and ALTA, have limited capabilities for analyzing different types of advanced solar cells based on different materials. That is why new simulation tools must be considered for a further work dedicated to reliability studies and experimental analyses of metal oxide solar cells. The thermal stability of such devices is essential during solar cell operation. It could be noted that the $\mathrm{Cu}_{2} \mathrm{O}: \mathrm{N}$ layer is very stable because its annealing for $90 \mathrm{~min}$ does not degrade its nitrogen-doping, as reported by Ye F. et al. [37].

\section{Conclusions}

The optimization of a silicon tandem heterojunction solar cell with a $\mathrm{Cu}_{2} \mathrm{O}$ absorber layer has been analyzed by numerical modeling based on its splitting into two subcells: a $\mathrm{ZnO} / \mathrm{Cu}_{2} \mathrm{O}$ top subcell and a c-Si bottom one. The buffer layer thickness and affinity are essential parameters for implementation of such devices defined by a low conduction band offset.

The optical characteristics of a $\mathrm{Cu}_{2} \mathrm{O}$ heterojunction solar cell were obtained by numerical modeling, allowing the evaluation of optical losses and determination of maximum absorptance of the device. 
A comprehensive characterization (morphological, structural, and optical) of the copper oxide layer with nitrogen doping enables us to propose the metal oxide heterojunction solar cell with nitrogen as a promising candidate for advanced high efficiency solar cells.

The main reliability parameters of metal oxide solar cells, namely the failure rate and degradation degree, were calculated and further work will stress the influence on electrical and optical properties of these devices from the thermal stability point of view.

Author Contributions: Conceptualization, L.F., I.C., and Ø.N.; methodology, L.F., I.C., R.K., and D.C.; formal analysis, L.F.; investigation, L.F., I.C., R.K., C.V., L.B., and D.S.; funding acquisition, L.F. and I.C.; software, S.F. and D.C.; validation, L.F., I.C., Ø.N., J.P.C., and D.C.; resources, I.C., R.K., and L.F.; data curation, S.F.; writing-original draft preparation, L.F., I.C., and S.F.; writing-review and editing, L.F., and I.C.; visualization, L.F. and I.C.; supervision, L.F., I.C., and J.P.C.; project administration, J.P.C., Ø.N., E.M., L.F., and I.C. All authors have read and agreed to the published version of the manuscript.

Funding: This research received no external funding.

Acknowledgments: This work was supported by the project "Multiscale in modelling and validation for solar photovoltaics" (Multiscale Solar) MP1406, 2015-2019, for IPVF (Institute Photovoltaïque de l'Île de France)-GeePs, PUB (Polytechnic University of Bucharest) and INOE, funded by the European Commission through COST program. This research activity was conducted under the research project "High-performance tandem heterojunction solar cells for specific applications (SOLHET)", for IFE, UiO, PB and INOE funded by the Research Council of Norway (RCN), project no. 251789, and the Romanian Executive Agency for Higher Education, Research, Development and Innovation Funding (UEFISCDI), contracts no. 34/2016 and no. 35/2016, through the M-ERA.NET program, and project no. PN 19_18.01.01/2019, Ad. Act. 2020, for INOE, funded by Ministry of Research and Innovation (MCI), through the NUCLEU program and institutional project 19PFE/2018, Stage IV/2020.

Conflicts of Interest: The authors declare no conflict of interest.

\section{References}

1. Wang, Y.; Miska, P.; Pilloud, D.; Horwat, D.; Mücklich, F.; Pierson, J.F. Transmittance enhancement and optical band gap widening of $\mathrm{Cu}_{2} \mathrm{O}$ thin films after air annealing. J. Appl. Phys. 2014, 115, 073505. [CrossRef]

2. Jung, Y.S.; Choi, H.W.; Kim, K.H. Properties of p-type $\mathrm{N}$-doped $\mathrm{Cu}_{2} \mathrm{O}$ thin films prepared by reactive sputtering. Jpn. J. Appl. Phys. 2014, 53, 11RA10. [CrossRef]

3. Siddiqui, H.; Parra, M.R.; Pandey, P.; Singh, N.; Qureshi, M.S.; Haque, F.Z. A review: Synthesis, characterization and cell performance of $\mathrm{Cu}_{2} \mathrm{O}$ based material for solar cells. Orient. J. Chem. 2012, 28, 1533-1545. [CrossRef]

4. Wang, Y.; Ghanbaja, J.; Horwat, D.; Yu, L.; Pierson, J.F. Nitrogen chemical state in N-doped $\mathrm{Cu}_{2} \mathrm{O}$ thin films. Appl. Phys. Lett. 2017, 110, 131902. [CrossRef]

5. Sberna, P.M.; Crupi, I.; Moscatelli, F.; Privitera, V.; Simone, F.; Miritello, M. Sputtered cuprous oxide thin films and nitrogen doping by ion implantation. Thin Solid Film. 2016, 600, 71-75. [CrossRef]

6. Mitroi, R.M.; Ninulescu, V.; Fara, L. Tandem solar cells based on $\mathrm{Cu}_{2} \mathrm{O}$ and c-Si subcells in parallel configuration: Numerical simulation. Int. J. Photoenergy 2017, 2017, 1-6. [CrossRef]

7. Takiguchi, Y.; Miyajima, S. Device simulation of cuprous oxide heterojunction solar cells. Jpn. J. Appl. Phys. 2015, 54, 112303. [CrossRef]

8. Nordseth, O.; Fara, L.; Kumar, R.; Foss, S.E.; Dumitru, C.; Muscurel, V.F.; Drăgan, F.; Crăciunescu, D.; Bergum, K.; Haug, H.; et al. Electro-optical modeling of a $\mathrm{ZnO} / \mathrm{Cu}_{2} \mathrm{O}$ subcell in a silicon-based tandem heterojunction solar cell. In Proceedings of the 33rd European Photovoltaic Solar Energy Conference and Exhibition, Amsterdam, The Netherlands, 25-29 September 2017; pp. 172-177. [CrossRef]

9. Nordseth, O.; Haug, H.; Kumar, R.; Bergum, K.; Drăgan, F.; Craciunescu, D.; Fara, L.; Chilibon, I.; Monakhov, E.; Foss, S.E.; et al. Performance optimization of a four-terminal $\mathrm{Cu}_{2} \mathrm{O} / \mathrm{c}-\mathrm{Si}$ Tandem heterojunction solar cell. In Proceedings of the 35th European Photovoltaic Solar Energy Conference and Exhibition, Bruxelles, Belgium, 24-28 September 2018; pp. 29-34. [CrossRef]

10. Dumitru, C.; Fara, L.; Nordseth, O.; Chilibon, I.; Kumar, R.; Svensson, B.G.; Dragan, F.; Muscurel, V.; Craciunescu, D.; Sterian, P. Electro-optical analysis and numerical modeling of $\mathrm{Cu}_{2} \mathrm{O}$ as the absorber layer in advanced solar cells. In Proceedings of the 2018 International Conference on Photovoltaic Science and Technologies (PVCon), Ankara, Turkey, 4-6 July 2018; pp. 1-7. [CrossRef] 
11. Chilibon, I.; Fara, L.; Nordseth, O.; Kumar, R.; Svensson, B.G.; Sterian, P.; Dumitru, C.; Dragan, F.; Muscurel, V.; Vasiliu, C. Structural and electrical analysis of $\mathrm{Cu}_{2} \mathrm{O}$ layers for solar cell application. Ann. Acad. Rom. Sci. 2018, 11, 53-60.

12. Chilibon, I.; Fara, L.; Nordseth, O.; Kumar, R.; Svensson, B.G.; Sterian, P.; Dumitru, C.; Dragan, F.; Muscurel, V.; Vasiliu, C. Characterization of $\mathrm{Cu}_{2} \mathrm{O}$ thin films used in solar cells by fluorescence and FTIR spectroscopy. Ann. Acad. Rom. Sci. Ser. Sci. 2018, 11, 61-68.

13. Lloyd, M.A.; Siah, S.C.; Brandt, R.E.; Serdy, J.; Johnson, S.W.; Lee, Y.S.; Buinassisi, T. Intrinsic defect engineering of cuprous oxide to enhance electrical transport properties for photovoltaic applications. In Proceedings of the IEEE 40th Photovoltaic Specialists Conference (PVSC), Denver, CO, USA, 8-13 June 2014; Volume 2016, pp. 3443-3445.

14. Tolstova, Y.; Omelchenko, S.T.; Blackwell, R.E.; Shing, A.M. Polycrystalline $\mathrm{Cu}_{2} \mathrm{O}$ photovoltaic devices incorporating Zn (O, S) window layers. Sol. Energy Mat. Sol. Cells 2017, 160, 340-345. [CrossRef]

15. Minami, T.; Nishi, Y.; Miyata, T. High-efficiency $\mathrm{Cu}_{2} \mathrm{O}$-based heterojunction solar cells fabricated using a $\mathrm{Ga}_{2} \mathrm{O}_{3}$ thin film as n-type layer. Appl. Phys. Express 2013, 6, 044101. [CrossRef]

16. Robertson, J.; Falabretti, B. Band offsets of high K gate oxides on III-V semiconductors. J. Appl. Phys. 2006, 100, 014111. [CrossRef]

17. Brandt, R.E.; Young, M.; Hejin, H.P.; Dameron, A.; Chua, D.; Lee, S.Y.; Teeter, G.; Gordon, R.; Buonassisi, T. Band offsets of n-type electron-selective contacts on cuprous oxide $\left(\mathrm{Cu}_{2} \mathrm{O}\right)$ for photovoltaics. Appl. Phys. Lett. 2014, 105, 263901. [CrossRef]

18. PV Lighthouse. Available online: https://www.pvlighthouse.com.au/ (accessed on 20 January 2020).

19. Baker-Finch, S.C.; McIntosh, K.R. OPAL 2: Rapid optical simulation of silicon solar cells. In Proceedings of the 38th IEEE Photovoltaic Specialists Conference, Austin, TX, USA, 3-8 June 2012; pp. 265-271. [CrossRef]

20. Dumitru, C.; Muscurel, V.; Nordseth, O.; Fara, L.; Sterian, P. Optimization of electro-optical performance and material parameters for a tandem metal oxide solar cell. In Proceedings of the International Conference on Computational Science and Its Applications-ICCSA, Melbourne, Australia, 2-5 July 2018; pp. 573-582. [CrossRef]

21. Murali, D.S.; Kumar, S.; Choudhary, R.J.; Wadikar, A.D.; Jain, M.K.; Subrahmanyam, A. Synthesis of $\mathrm{Cu}_{2} \mathrm{O}$ from $\mathrm{CuO}$ thin films: Optical and electrical properties. AIP Adv. 2015, 5, 047143. [CrossRef]

22. Bennett, J.M.; Mattson, L. Introduction to Surface Roughness and Scattering; Optical Society of America: Washington, DC, USA, 1989.

23. Nordseth, O.; Kumar, R.; Bergum, K.; Chilibon, I.; Fara, L.; Foss, S.E.; Monakhov, E. Nitrogen-doped Cu ${ }_{2} \mathrm{O}$ thin films for photovoltaic applications. Materials 2019, 12, 3038. [CrossRef] [PubMed]

24. Lee, S.W.; Lee, Y.S.; Heo, J.; Siah, S.C.; Chua, D.; Brandt, R.; Kim, S.B.; Mailoa, J.P.; Buonassisi, T.; Gordon, R.G. Improved $\mathrm{Cu} 2 \mathrm{O}$-based solar cells using atomic layer deposition to control the $\mathrm{Cu}$ oxidation state at the p-n junction. Adv. Energy Mater. 2014, 4, 1301916. [CrossRef]

25. JCPDS 78-2076 for $\mathrm{Cu}_{2} \mathrm{O}$, JCPDS 03-0879 for $\mathrm{Cu}_{4} \mathrm{O}_{3}$, JCPDS 48-1548 for CuO, and JCPDS 85-1326 for Cu; International Centre for Diffraction Data-JCPDS: Newtown Square, PA, USA, 1996.

26. Nakano, Y.; Saeki, S.; Morikawa, T. Optical bandgap widening of p-type $\mathrm{Cu}_{2} \mathrm{O}$ films by nitrogen doping. Appl. Phys. Lett. 2009, 94, 022111. [CrossRef]

27. Reddy, M.H.P.; Pierson, J.F.; Uthanna, S. Structural, surface morphological, and optical properties of nanocrystalline $\mathrm{Cu}_{2} \mathrm{O}$ and $\mathrm{CuO}$ films formed by RF magnetron sputtering: Oxygen partial pressure effect. Phys. Status Solidi A 2012, 209, 1279-1286. [CrossRef]

28. Ogwu, A.A.; Darma, T.H. A reactive magnetron sputtering route for attaining a controlled core-rim phase partitioning in $\mathrm{Cu}_{2} \mathrm{O} / \mathrm{CuO}$ thin films with resistive switching potential. J. Appl. Phys. 2013, 113, 183522. [CrossRef]

29. Su, J.; Niu, Q.; Sun, R.; An, X.; Zhang, Y. Investigation of $\mathrm{Cu}_{2} \mathrm{O}$ films sputtered with ceramic target: Effect of RF power. J. Optoelectron. Adv. M. 2018, 20,441-444.

30. Gong, J.B.; Dong, W.L.; Dai, R.C.; Wang, Z.P.; Zhang, Z.M.; Ding, Z.J. Thickness dependence of the optical constants of oxidized copper thin films based on ellipsometry and transmittance. Chin. Phys. B 2014, 23, 1-5. [CrossRef]

31. Gan, J.; Venkatachalapathy, V.; Svensson, B.G.; Monakhov, E.V. Influence of target power on properties of $\mathrm{Cu}_{\mathrm{x}} \mathrm{O}$ thin films prepared by reactive radio frequency magnetron sputtering. Thin Solid Film. 2015, 594, 250-255. [CrossRef] 
32. Li, J.; Mei, Z.; Liu, L.; Liang, H.; Azarov, A.; Kuznetsov, A.; Liu, Y.; Ji, A.; Meng, Q.; Du, X. Probing defects in nitrogen-doped $\mathrm{Cu}_{2}$ O. Sci. Rep. 2014, 4, 7240. [CrossRef] [PubMed]

33. Reliability Engineering Software Products-ReliaSoft. Available online: https://www.reliasoft.com (accessed on 20 January 2019).

34. Sharma, V.; Chandel, S.S. Performance and degradation analysis for long term reliability of solar photovoltaic systems: A review. Renew. Sustain. Energy Rev. 2013, 27, 753-767. [CrossRef]

35. Guo, D.; Brinkman, D.; Shaik, A.R.; Ringhofer, C.; Vasileska, D. Metastability and reliability of CdTe solar cells. J. Phys. D Appl. Phys. 2018, 51, 15. [CrossRef]

36. Fara, L.; Craciunescu, D. Reliability analysis of photovoltaic systems for specific applications. In Reliability and Ecological Aspects of Photovoltaic Modules; Gok, A., Ed.; Intech Open: London, UK, 2020; pp. 79-92.

37. Ye, F.; Zeng, J.J.; Qiu, Y.B.; Cai, X.M.; Wang, B.; Wang, H.; Zhang, D.P.; Fan, P.; Roy, V.A.L. Deposition-rate controlled nitrogen-doping into cuprous oxide and its thermal stability. Thin Solid Film. 2019, 674, 44-51. [CrossRef]

(C) 2020 by the authors. Licensee MDPI, Basel, Switzerland. This article is an open access article distributed under the terms and conditions of the Creative Commons Attribution (CC BY) license (http://creativecommons.org/licenses/by/4.0/). 